\title{
Is It In The Name, Or In The Game? Can News Affect Firm Value? A Case For Athletes Sponsored By Nike, Inc. \\ Lincoln Cohoon, Roger Williams University Marian Extejt, Roger Williams University \\ Michael Melton, (E-mail: mmelton@rwu.edu), Roger Williams University
}

\begin{abstract}
Until recently, little of the celebrity endorsement literature has focused on how the activities of an athlete affect a company's value. Those that do, tend to focus on the impact of one star, such as Tiger Woods in golf, on a variety of companies. This paper adopts the behavioral finance viewpoint and examines the impact of news relating to various sport stars' performance, both on and off the field, on the sponsoring/endorsing firm's value. This research analyzes the impact across seven sports under Nike Inc. 's endorsement umbrella. In doing so, this study finds that news pertaining to the very best "athletic stars" in their respective sports do not directly affect Nike's stock price. In fact, the only sport having a significant impact on stock price is professional golf. Surprisingly, news relating to basketball, the sport generating one the largest endorsement expenses for Nike, Inc., did not have a significant influence on stock price. Such results lead the authors to conclude that 1) the success of those sports stars under Nike's endorsement umbrella does not directly add value to the firm, and 2) other factors may play a role in influencing investor behavior, to include airtime, public perception, and the size of the market, itself.
\end{abstract}

\section{INTRODUCTION}

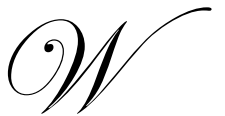

hen someone asks you about Mia Hamm, you may say American soccer. When someone asks you about Tiger Woods, you are probably going to answer with Nike. In marketing, they call it "branding." From a financial standpoint, specifically behavioral finance, this may constitute investors reacting to information. With that in mind, many companies today wish to stress the quality and importance of their product through the endorsement of celebrities or athletes, in turn, hopefully adding value to their stock price.

Although Nike Inc. is not required to release information on any one individual endorsement contract, as of fiscal year 2006, Sports Business Journal reported that the company valued it's endorsement contracts to be worth over a staggering \$1.9 billion (Kaplan, 2006). For its two major endorsers, Tiger Wood (PGA) possesses a 5-year, $\$ 100$ million contract and LeBron James (NBA) possesses a 7-year, $\$ 90$ million contract. Knowing that Nike's nearest U.S. competitor, Reebok, now a subsidiary of Adidas AG, valued its endorsement deals at roughly \$200 million, one could question whether Nike could possibly receive adequate return on its investment.

With the advent of technology, sports enthusiasts and ordinary fans alike, have more sporting events and sporting news at their disposal than ever before. Satellite radio outlets such as XM Radio and Sirius, as well as digital cable and satellite television provide the opportunity to listen or watch almost any event in any sport, domestic and abroad. Sports such as football (college, NFL, and Canadian Football League), baseball (college and MLB), basketball (college, WNBA and NBA), cycling (Tour de France), hockey (college and NHL), soccer (domestic and foreign), golf (LPGA and PGA), tennis (Wimbledon and the APT and WTA tours), and even NASCAR, are available 24 hours a day.

More news and game coverage means more opportunity for people to see sport stars branding the products. In the behavioral finance framework, one would assume that more opportunities are provided for investors to react to athletes' 
performances, possibly creating psychological biases. These biases could foster a link in the consumer's mind between the performance of or news concerning an athlete and the quality of the products s/he endorses.

The primary goal of this paper is to determine the impact of news pertaining to these "sports stars," both in and outside their stage, on Nike Inc.'s stock price. The choice of Nike Inc. as the individual benchmark is twofold. First, it is easy to consider Nike as the endorsement leader in the industry. Second, the company clearly has the largest number of athletes across various sports that are considered the "very best," assuring high visibility. The sports chosen to be represented in this sample (baseball, basketball, cycling, football, golf, soccer, and tennis) are those that carry the most "air time" on broadcast media outlets. The athletes were chosen based on the amount of time they were listed, both in print and in photos, in Nike Inc.'s annual report over the same time.

\section{LITERATURE REVIEW}

Past research has focused mainly on the use of celebrity endorsers in product advertising and how such endorsements influence consumer behavior. An early example of this line of inquiry is Kamins, Brand, Hoeke, and Moe (1989) who examine theories of credibility based on a celebrity's perceived trustworthiness, expertise, and familiarity. Ohanian (1991) related those three sources of celebrity credibility to consumers' intention to purchase products. Miciak and Shanklin (1994) and Erdogan, Baker and Tagg (2001) examined the importance of similar celebrity characteristics on the manager's decision of selecting the celebrity as an endorser. Other studies examined similar conditions that may influence the process of identification. Kahl and Homer (1985) studied how the attractiveness of a celebrity influenced consumer behavior. Buhr, Simpson, and Pryor (1987) and O'Mahony and Meenaghan (1997) examined how the perceived celebrity's expertise with the product influenced the identification process. Finally, Mowen and Brown (1981) and Tripp, Jensen, and Carlson (1994) analyzed the influence of celebrity endorsement based on the number of products endorsed as well as the number of potential exposures.

Similar to that research, several past studies have employed event study methodology to evaluate the plausible affects on firm value. With respect to advertising, Bobinski and Ramirez (1994) examine the effects of financial-relations advertising on stock price and volume, finding no significant between the two. In contrast, Mathur and Mathur (1995) find that the announcement of advertising slogan changes positively affects firm value. Extending this research, Mathur and Mathur, (1996) studied the impact a firm's decision to initiate new advertising agency-client relations have on its market value. They find a positive wealth effect associated with the announcements of new accounts with advertising agencies not previously tied to the firm. In contrast, they found a negative impact for firms announcing accounts with an existing agency.

Another stream of literature, with contradictory findings, looks at how announcements of event sponsorship influence sponsoring firms' value. Farrell and Frame (1997) found when analyzing 26 Olympic sponsorship announcements that there was a negative impact on the sponsoring company. In contrast, Miyazaki and Morgan (2001) found that when analyzing 27 sponsorship announcements from the 1996 Summer Olympics, there was a significant stock increase for each of the companies. The findings of Clark, Cornwell, and Pruitt (2002) showed that sponsorship in various sporting stadiums had a positive effect on both large and small companies. The authors suggest that it gives the small companies visibility and in larger companies, it shows investors that the upper management has confidence in the future of the company

Combining the two streams of literature above, Agrawal and Kamakura (1995) use the event study methodology to examine the potential profitability of endorsement contracts. Analyzing 110 celebrity endorsement contracts, the authors found that these announcements had a positive impact on stock price, suggesting that these contracts are a worthwhile investment. Using similar methodology, Farrell, Karels, Monfort, and McClatchy (2000) examined the impact Tiger Wood's tournament performance had on the endorsing firm's value. The authors find a positive and significant impact of Tiger's performance on Nike's excess returns.

Cornwall, Pruitt, and Van Ness (2005) found a positive correlation between official sports sponsorship announcements and the sponsor's stock price. On the contrary, Kinney and Bell (2003) found that there was a neutral or 
negative effect on a majority of the 61 announcements they looked at. Negative stock results were found in American football and tennis while there were positive effects seen with sponsorship in baseball and the Olympics.

In order to extend the currently literature, this paper examines the impact of news announcements concerning athletes from various sports under the endorsement umbrella of Nike, Inc. Building on prior research of Farrell, Karels, Monfort, and McClatchey (2000) and Agrawal and Kamakura (1995), this work investigates which sport and "sports star," if any, may have the most significant impact on firm value.

\section{DATA AND METHODOLOGY}

This study examines the impact of news announcements from January 4, 2001 to August 8, 2006 regarding athletes from various sports under the Nike, Inc. endorsement umbrella on that firm's stock price. Pertinent news releases were collected for several sources, including the Wall Street Journal, Sports Illustrated, Sports Business Journal, and the World Wide Web. Stock prices for this same period were collected from SDS MarketWatch ${ }^{\mathrm{i}}$. As stated, the sports chosen to be represented in the sample were those that carry the most "air time" on the various media outlets. The athletes were chosen based on the amount of time they were listed, both in print and in photos, in Nike Inc.'s annual report over the same period. Table 1 lists the 30 athletes by sports below.

Table 1

\section{Listing Of Athletes}

\begin{tabular}{|c|c|c|c|c|c|}
\hline Sport & Athlete \#1 & Athlete \#2 & Athlete \#3 & Athlete \#4 & Athlete \#5 \\
\hline Baseball & Bobby Crosby & Ken Griffey, Jr. & Derek Jeter & Pedro Martinez & Alex Rodriguez \\
\hline Basketball & Carmelo Anthony & Kobe Bryant & Vince Carter & LeBron James & Jason Kidd \\
\hline Cycling & Lance Armstrong & & & & Michael Vick \\
\hline Football & Tom Brady & Brett Favre & $\begin{array}{c}\text { Ladainian } \\
\text { Tomlinson }\end{array}$ & Brian Urlacher & Miger Woods \\
\hline Golf & Stewart Cink & David Duval & Grace Park & Michelle Wei & Tiger \\
\hline Soccer & Freddy Adu & Mia Hamm & Wayne Rooney & Fernando Torres & \\
\hline Tennis & Andre Agassi & Rafeal Nadal & Pete Sampras & Maria Sharapova & Serena Williams \\
\hline
\end{tabular}

The selection of relevant news announcements were based on accomplishments and awards, signifying the athletes' success in his or her sport. Such accomplishments would include winning or high placed finishes in major sporting events that would garner world recognition. Examples include the World Series for baseball, the Tour de France for cycling, any professional golf tournament, and so on. In addition, news targeting the surpassing of major records or milestones in their respective sports was included. Concerning awards, several end-of-the-season awards are given to those players exhibiting exceptional performance throughout the year. Here, examples include NBA All-Stars, NFL ProBowl, baseball's Golden Gloves, etc. Finally, other relevant news announcements include signing of new contracts, trades amongst teams, and activities that garnered national or global media attention. In all, 314 pieces of news were collected for these 30 athletes. Table 2 lists a variety of examples of these accomplishments, awards, and significant news for the various athletes under Nike's endorsement umbrella. 
Table 2

Example Listing Of Accomplishments

\begin{tabular}{|c|c|c|c|}
\hline Sport & Athlete & Date & Activity \\
\hline Tennis & Andre Agassi & $1 / 18 / 00$ & Australian Open \\
\hline Baseball & Ken Griffey Jr & $7 / 11 / 00$ & MLB All Star Game \\
\hline Soccer & Mia Hamm & $9 / 29 / 00$ & US Women's Soccer Olympic Silver \\
\hline Basketball & Jason Kidd & $10 / 3 / 00$ & US Basketball Olympic Gold Medal \\
\hline Tennis & Andre Agassi & $7 / 24 / 01$ & ATP Tour Win \\
\hline Cycling & Lance Armstrong & $7 / 30 / 01$ & Wins Tour de France \\
\hline Soccer & Wayne Rooney & $2 / 12 / 03$ & International Debut \\
\hline Baseball & Alex Rodriguez & $11 / 13 / 02$ & Gold Glove \\
\hline Football & Michael Vick & $1 / 6 / 03$ & Falcons upset Packers in playoff game \\
\hline Soccer & Mia Hamm & $10 / 13 / 03$ & US women's soccer $3^{\text {rd }}$ in World Cup \\
\hline Soccer & Freddy Adu & $11 / 18 / 03$ & Signs with DC United \\
\hline Football & Brett Favre & $12 / 23 / 03$ & Greatest game of career (father's death) \\
\hline Football & Ladainian Tomlinson & $2 / 9 / 04$ & NFL Pro Bowl \\
\hline Basketball & Kobe Bryant & $2 / 17 / 04$ & NBA All Star Game \\
\hline Soccer & Freddy Adu & $4 / 19 / 04$ & First professional goal \\
\hline Basketball & LeBron James & $4 / 23 / 04$ & Rookie of the Year \\
\hline Soccer & Fernando Torres & $4 / 29 / 04$ & First International Goal \\
\hline Baseball & Alex Rodriguez & $5 / 5 / 04$ & Youngest player to hit $350 \mathrm{HR}$ \\
\hline Tennis & Maria Sharapova & $6 / 8 / 04$ & WTA win \\
\hline Basketball & LeBron James & $1 / 20 / 05$ & Youngest player to record triple-double \\
\hline Golf & Tiger Woods & $1 / 24 / 05$ & Buick Invitational \\
\hline Football & Tom Brady & $2 / 7 / 05$ & Patriots win Super Bowl \\
\hline Baseball & Ken Griffey Jr & $9 / 5 / 05$ & Ties Mickey Mantle for $12^{\text {th }}$ all time HR \\
\hline Baseball & Derek Jeter & $9 / 6 / 05$ & Played in $1500^{\text {th }}$ career game \\
\hline
\end{tabular}

To test the significance of these various news releases on Nike's value, this study views the releases as "event dates." Similar to previous research, this study measures the net benefit, if any, that such news has on the endorsing firm. Using excess returns as the measure of net benefit, we analyze whether or not the new information is viewed favorably (poorly) by the market, thus driving stock price for Nike in a positive (negative) fashion. A traditional Logit model is incorporated. The regression equation to be estimated is as follows:

$\mathrm{ER}_{\text {NIKE }}=\alpha_{0}+\beta_{1}$ NEWS $+\beta_{2}$ COMPETITION $+\varepsilon_{\mathrm{i}}^{\mathrm{ii}}$

where ER measures the Nike's excess return. NEWS represents a dummy variable where 1 if a significant piece of news, 0 otherwise. Multiple NEWS variables will exist for the various numbers of athletes in each sports category. COMPETITION represents an equally-weighted excess-return average of the leading competitor of Nike in the various sports being tested. For this study, the company Adidas is chosen, both for its global market share in the sports being analyzed, and for its current purchases of companies such as Reebok. Like Farrell, Karels, Monfort, and McClatchy (2000), this variable will act as an independent variable to control for broad industry effects that could potentially influence Nike's excess returns. In addition, any significance in this variable may identify additional impacts across the industry.

A second test is incorporated into the study to determine whether the news announcements significantly influenced Nike's Competition, namely, Adidas. Similar to Equation 1, the new model is as follows:

$\mathrm{ER}_{\mathrm{ADIDAS}}=\alpha_{0}+\beta_{1} \mathrm{NEWS}+\varepsilon_{\mathrm{i}}$

where ER measures the Nike's excess return. NEWS represents a dummy variable where 1 if a significant piece of news, 0 otherwise. Multiple NEWS variables will exist for the various numbers of athletes in each sports category. 
Lastly, a third test measures the impact of sports news, as groups, on firm value. This test is conducted to see if there is one general sport influencing Nike's risk-adjusted returns. The equation is:

ER $_{\text {NIKE }}=\alpha_{0}+\beta_{1}$ BASEBALL $+\beta_{2}$ BASKETBALL $+\beta_{3}$ CYCLING $+\beta_{4}$ FOOTBALL $+\beta_{5}$ GOLF $+\beta_{6}$ SOCCER + $\beta_{7}$ TENNIS $+\varepsilon_{\mathrm{i}}$

where ER measures the Nike's excess return. The independent variables (SPORTS) are represented by multiple numbers signifying the number of news releases for that particular sport on a given day.

\section{RESULTS}

Table 1 lists the results for equation (1). As Table 1 indicates, the only sport star to have a positive and significant impact on Nike's excess returns is Tiger Woods.

Table 3

OLS Regression For Nike, Inc. Excess Returns As Impacted By Various Sports Stars

\begin{tabular}{|c|c|c|c|}
\hline Baseball & Coefficients & P-value & R-Square \\
\hline Intercept & 0.0004 & 0.4744 & 0.0375 \\
\hline Jeter & -0.0037 & 0.5981 & \\
\hline Rodriguez & 0.0006 & 0.9132 & \\
\hline Griffey Jr & 0.0097 & 0.3540 & \\
\hline Martinez & 0.0013 & 0.8749 & \\
\hline Crosby & -0.0252 & 0.2263 & \\
\hline Industry & 0.0020 & 0.6835 & \\
\hline Football & Coefficients & P-value & R-Square \\
\hline Intercept & 0.0003 & 0.5259 & 0.0381 \\
\hline Vick & 0.0073 & 0.4037 & \\
\hline Brady & -0.0021 & 0.8239 & \\
\hline Urlacher & -0.0170 & 0.1574 & \\
\hline Favre & 0.0101 & 0.3236 & \\
\hline Tomlinson & 0.0083 & 0.5081 & \\
\hline Industry & 0.0017 & 0.5635 & \\
\hline Cycling & Coefficients & P-value & R-Square \\
\hline Intercept & 0.0004 & 0.4571 & 0.0361 \\
\hline Armstrong & -0.0024 & 0.7477 & \\
\hline Industry & 0.0020 & 0.7116 & \\
\hline Tennis & Coefficients & P-value & R-Square \\
\hline Intercept & 0.0003 & 0.5211 & 0.0372 \\
\hline Agassi & -0.0060 & 0.4170 & \\
\hline Williams & 0.0027 & 0.8211 & \\
\hline Sampras & 0.0060 & 0.6187 & \\
\hline Nadal & 0.0054 & 0.3692 & \\
\hline Sharapova & 0.0019 & 0.7705 & \\
\hline Industry & 0.0015 & 0.7220 & \\
\hline
\end{tabular}

\begin{tabular}{|c|c|c|c|}
\hline Basketball & Coefficients & P-value & R-Square \\
\hline Intercept & 0.0005 & 0.3192 & 0.0384 \\
\hline Jeter & -0.0038 & 0.5979 & \\
\hline Rodriguez & 0.0003 & 0.9542 & \\
\hline Griffey Jr & 0.0090 & 0.3977 & \\
\hline Martinez & 0.0001 & 0.9878 & \\
\hline Crosby & -0.0299 & 0.1582 & \\
\hline Industry & 0.0020 & 0.7347 & \\
\hline Golf & Coefficients & P-value & R-Square \\
\hline Intercept & 0.0007 & 0.1872 & 0.0403 \\
\hline Woods & 0.0077 & $0.0289 * *$ & \\
\hline Wie & 0.0002 & 0.9819 & \\
\hline Park & -0.0067 & 0.6551 & \\
\hline Duval & 0.0016 & 0.8988 & \\
\hline Cink & -0.0052 & 0.6722 & \\
\hline Industry & 0.0028 & 0.2645 & \\
\hline Soccer & Coefficients & P-value & R-Square \\
\hline Intercept & 0.0003 & 0.4954 & 0.0362 \\
\hline Hamm & 0.0042 & 0.7262 & \\
\hline Adu & 0.0021 & 0.8371 & \\
\hline Torres & 0.0055 & 0.7336 & \\
\hline Rooney & 0.0002 & 0.9882 & \\
\hline Industry & 0.0019 & 0.3959 & \\
\hline
\end{tabular}

This result concurs with that of Farrell, Karels, Monfort and McClatchy (2000), finding a positive and significant impact of news on Tiger's performance on Nike's excess returns. This suggests that the market values the additional publicity that Nike receives when Tiger makes the news. Surprisingly, athletes who produces as much, if not more 
noteworthy news points, did not have the same impact, For example, Derek Jeter who participates in farm more "public" athletic events (162 games versus 28 tournaments for Tiger), did not significantly impact Nike's price. Last, the control variable (Industry) was not significant in any of the seven test using Equation (1).

In the next test, this study builds on the prior literature and introduces a new analysis. Using Equation (2), this study chose to examine the impact such news could have on Nike's direct competition, namely, Adidas AG. If any news on the athletes under Nike's endorsement umbrella significantly affected Adidas' stock price, one could conclude that an "indirect" market reaction does exist. Figure 4 summarizes the results.

Table 4

OLS Regression For Adidas, AG Excess Returns As Impacted By Various Sports Stars

\begin{tabular}{|c|c|c|c|}
\hline Baseball & Coefficients & P-value & R-Square \\
\hline Intercept & 0.0008 & 0.1218 & 0.0160 \\
\hline Jeter & -0.0004 & 0.9596 & \\
\hline Rodriguez & -0.0014 & 0.7935 & \\
\hline Griffey Jr & -0.0035 & 0.7329 & \\
\hline Martinez & -0.0058 & 0.4618 & \\
\hline Crosby & -0.0239 & 0.2402 & \\
\hline Football & Coefficients & P-value & R-Square \\
\hline Intercept & 0.0007 & 0.1492 & 0.0227 \\
\hline Vick & -0.0030 & 0.7260 & \\
\hline Brady & 0.0003 & 0.9768 & \\
\hline Urlacher & 0.0220 & $0.0600^{*}$ & \\
\hline Favre & -0.0115 & 0.2497 & \\
\hline Tomlinson & -0.0078 & 0.5260 & \\
\hline Cycling & Coefficients & P-value & R-Square \\
\hline Intercept & 0.0007 & 0.1440 & 0.0231 \\
\hline Armstrong & -0.0045 & 0.5354 & \\
\hline Tennis & Coefficients & P-value & R-Square \\
\hline Intercept & 0.0008 & 0.1245 & 0.0162 \\
\hline Agassi & -0.0027 & 0.7060 & \\
\hline Williams & 0.0021 & 0.8606 & \\
\hline Sampras & -0.0071 & 0.5443 & \\
\hline Nadal & 0.0018 & 0.7603 & \\
\hline Sharapova & -0.0094 & 0.1481 & \\
\hline
\end{tabular}

\begin{tabular}{|c|c|c|c|}
\hline Basketball & Coefficients & P-value & R-Square \\
\hline Intercept & 0.0008 & 0.1137 & 0.0249 \\
\hline Bryant & 0.0012 & 0.8597 & \\
\hline James & -0.0019 & 0.8207 & \\
\hline Kidd & -0.0052 & 0.6493 & \\
\hline Carter & -0.0055 & 0.5904 & \\
\hline Anthony & -0.0166 & 0.1699 & \\
\hline & & & \\
\hline Golf & Coefficients & P-value & R-Square \\
\hline Intercept & 0.0005 & 0.2996 & 0.0301 \\
\hline Woods & 0.0041 & 0.2275 & \\
\hline Wie & 0.0093 & 0.3604 & \\
\hline Park & 0.0266 & 0.0642 & \\
\hline Duval & 0.0035 & 0.7653 & \\
\hline Cink & 0.0184 & 0.1165 & \\
\hline & & & \\
\hline Soccer & Coefficients & P-value & R-Square \\
\hline Intercept & 0.0007 & 0.1657 & 0.0158 \\
\hline Hamm & 0.0023 & 0.8476 & \\
\hline Adu & 0.0066 & 0.5149 & \\
\hline Torres & 0.0082 & 0.6012 & \\
\hline Rooney & -0.0083 & 0.5199 & \\
\hline \multicolumn{2}{|l}{} & \\
\hline & \multicolumn{2}{l}{} \\
\hline & & \\
\hline & & \\
\hline & & \\
\hline
\end{tabular}

* Significance at the $90 \%$ Confidence Level

In this test, only Brian Urlacher (NFL Football) had a significant impact on Adidas, AG. Such a result may imply that Brian is actually hurting Nike, by helping to increase Adidas' excess returns. Another interesting point is that those sports that are heavily watched in Adidas' home market (Soccer and Tennis) did not influence the returns of the Germanbased company.

The final test conducted in this study addresses the overall impact of the sport rather than the athlete. This analysis is necessary to determine whether or not Nike can view certain sports as credible investments. Using Equation (3) the results are presented in Table 5. 
Table 5

OLS Regression For Nike, Inc. Excess Returns As Impacted By Various Sports

\begin{tabular}{|c|c|c|}
\hline Sport & Coefficients & P-value \\
\hline Intercept & 0.0006 & 0.2547 \\
\hline Baseball & 0.0001 & 0.9536 \\
\hline Basketball & -0.0002 & 0.9483 \\
\hline Cycling & -0.0035 & 0.6374 \\
\hline Football & 0.0019 & 0.4641 \\
\hline Golf & 0.0064 & $0.0341 * *$ \\
\hline Soccer & 0.0039 & 0.4933 \\
\hline Tennis & 0.0016 & 0.6534 \\
\hline
\end{tabular}

* Significance at the $90 \%$ Confidence Level

Again, the only sport that is significant is golf. One may conclude that this result is directly related to Tiger Woods, his success and \#1 ranking in the world. An alternative explanation to this result is that Tiger Woods is one of the few athletes under Nike's endorsement umbrella that has a product contact with his name directly attached to it. From a behavioral standpoint, the market may have the tendency to correlate Tiger's success (as reported though the news being analyzed) with the product itself. As concluded by Ohanian (1991), perceived expertise is the most significant factor in explaining the consumer's intention to purchase. Thus, if Tiger is willing to compete with Nike's equipment and in Nike's clothing, it must be good. On the other hand, the authors find it interesting none of the other sports have the same impact on Nike's excess returns. Given the amount of news, combined with the notion that all of the athletes chosen in the sample are the top-ranked professionals for their sports, the market should react in a similar fashion. This result alone illustrates the need for additional research along this path.

\section{CONCLUSION}

The primary goal of this paper is to determine the impact of news pertaining to these respective "sports stars," both in and outside their stage, on Nike Inc.'s stock price. The choice of Nike Inc. as the individual benchmark is twofold. First, it is easy to consider Nike as the leader in the industry in athletic endorsements. Secondly, the company clearly has the largest number of athletes across various sports that are considered the "very best," assuring the most visibility.

Results indicate that no individual players from any sport other than Tiger Woods (professional golfer) significantly affect Nike Inc.'s excess returns. Surprisingly, news relating to basketball, the sport generating one the largest endorsement expenses for Nike, Inc., did not have a significant influence on stock price. Such results lead the authors to conclude that 1) the success of those sports stars under Nike's endorsement umbrella does not directly add value to the firm, and 2) other factors may play a role in influencing investor behavior, to include airtime, public perception, and the size of the market, itself. Concerning the second point, this research will hopefully act as a catalyst for future research to determine what other factors may exist today influencing investor's behavior.

\section{ENDNOTES}

\footnotetext{
${ }^{\mathrm{i}}$ Securities Dealings Systems MarketWatch is financial analysis platform used in the Gabelli School of Business. This platform can be found at www.sdsmarketwatch.com.

ii The extended equation for Baseball would look like:

$\mathrm{ER}_{\mathrm{NIKE}}=\alpha_{0}+\beta_{1}$ JETER $+\beta_{2}$ BRODRIGUEZ $+\beta_{3}$ GRIFFEY $+\beta_{4}$ MARTINEZ $+\beta_{5}$ CROSBY $+\varepsilon_{\mathrm{i}}$
} 


\section{REFERENCES}

1. Adams-Price, C. and A.O. Greene. 1990. Secondary attachments and adolescent self concept. Sex Roles. 22:187-198.

2. Agrawal, Jagdish and Wagner A. Kamakura. 1995. The Economic Worth of Celebrity Endorsers: An Event Study Analysis. Journal of Marketing. 59(3): 56-62

3. Buhr, T.A., T.L. Simpson, and B. Pryor. 1987. Celebrity Endorsers' Expertise and Perceptions of Attractiveness, Likability, and Familiarity. Psychological Reports. 60: 1307-1309

4. Cornwell, T. Bettina and Isabella Maignan. 1998. An International Review of Sponsorship Research. Journal of Advertising. Vol. 27.

5. Cornwell, T. Bettina and Donald P. Roy. 2003. Brand Equity's Influence on Responses to Event Sponsorship. Journal of Product \& Brand Management. Vol. 12, Issue 6.

6. Cornwell, T. Bettina, Stephen Pruitt, and John Clark. 2005. The Relationship between Major League Sports' Official Sponsorship Announcements and the Stock Prices of Sponsoring Firms. Journal of the Academy of Marketing Science. Vol. 33 (4): 401-412.

7. Erdogan, B.Z., M.J. Baker and S. Tagg. 2001. Selecting celebrity endorsers: the practitioner's perspective. Journal of Advertising Research, May-June. 39-48.

8. Farrell, Kathleen and W. Scott Frame. 1997. The Value of Olympic Sponsorships: Who Is Capturing Gold? Journal of Market-Focused Management.2(2)

9. Farrell, Kathleen, Gordon Karels, Kenneth Monfont, and Christine McClatchey. 2000. Celebrity Performance and Endorsement Value: The Case of Tiger Woods. Managerial Finance. 26 (7): 1-15.

10. Friedman, Hershey H. and Linda Friedman. 1979. Endorser Effectiveness by Product Type. Journal of Advertising Research. 19 (5): 63-71.

11. Kahle, Lynn B. and Pamela M. Homer. 1985. Physical Attractiveness of Celebrity Endorsers: A Social Adaptation Perspective. Journal of Consumer Research. 11 (March): 954-961.

12. Kaplan, D. 2006 Endorser bill for Nike nears \$2B. SportsBusiness Journal. October 9, 1.

13. Lane, Vicki and Robert Jacobson (1995) Stock Market Reactions to Brand Extention Announcements: The Effects of Brand Attitude and Familiarity, Journal of Marketing. 59 (January) 63-77

14. Mathur, Lynette K., Ike Mathur and Nanda Rangan. 1997. The Wealth Effects Associated with a Celebrity Endorser: The Michael Jordan Phenomenon. Journal of Advertising Research. 37 (May-June) 67-73.

15. McConnell, John J., and Chris J. Muscarella. 1985. Corporate Capital Expenditure Decisions and Market Value of the Firm. Journal of Financial Economics. 14: 399-422.

16. Miciak, A.R. and W.L. Shanklin. 1994. Choosing celebity endorsers. Marketing Management 3 (3) 50-59.

17. Miyazaki, A.D. and Morgan, A.G. 2001. Assessing Market Value of Event Sponsoring: Corporate Olympic Sponsorships. Journal of Advertising Research. Vol. 41

18. Ohanian, Roobina. 1991. The Impact of Celebrity Spokespersons' Perceived Image on Consumers' Intention to Purchase. Journal of Advertising Research. 31 (February/March): 46-54

19. O’Mahony, S. and T. Meenaghan. 1997. The impact of celebrity endorsemensts on consumers. Irish Marketing Review 10(2): 15-24.

20. Rappaport, Alfred (1986), Creating Shareholder Value: The New Standard for Business Performance. New York: The Free Press

21. Rappaport, Alfred (1987) Stock Market Signals to Managers, Harvard Business Review, (November/December), 57-62

22. Rust, Ronald and Richard W. Oliver. 1994. The Death of Advertising. Journal of Advertising. Vol. 23.

23. Till, Brian D., and Terence A. Shrimp. 1998. Endorsers in Advertising: The Case of Negative Celebrity Information. Journal of Advertising. 27 (1): 67-82 